\title{
Soil Characteristics and Lodgepole Pine (Pinus contorta var. latifolia) Performance Two Decades after Disk Trenching of Unburned and Broadcast-Burned Plots in Subboreal British Columbia
}

\author{
Jacob O. Boateng, ${ }^{1}$ Jean L. Heineman, ${ }^{2}$ Lorne Bedford, ${ }^{1}$ and Amanda F. Linnell Nemec ${ }^{3}$ \\ ${ }^{1}$ Resource Practices Branch, B.C. Ministry of Forests, Lands, and Natural Resource Operations, P.O. Box 9513 Station Provincial \\ Government, Victoria, BC, Canada V8W 9C2 \\ ${ }^{2}$ J. Heineman Forestry Consulting, 2125 E. 5th Avenue, Vancouver, BC, Canada V5N 1 M5 \\ ${ }^{3}$ International Statistics and Research Corp., P.O. Box 39, Brentwood Bay, BC, Canada V8M 1R3 \\ Correspondence should be addressed to Jacob O. Boateng, jacob.boateng@gov.bc.ca \\ Received 4 May 2011; Revised 3 August 2011; Accepted 26 August 2011 \\ Academic Editor: Marie-Charlotte Nilsson
}

Copyright ( $\odot 2011$ Jacob O. Boateng et al. This is an open access article distributed under the Creative Commons Attribution License, which permits unrestricted use, distribution, and reproduction in any medium, provided the original work is properly cited.

We examined the effects of low-impact broadcast-burning and disk-trenching planting position (control, hinge, trench) on soil characteristics and lodgepole pine foliar nutrition and growth over two decades at a subboreal site in British Columbia, Canada. Broadcast burning had virtually no effect on either the bulk density or chemical properties of soil. In contrast, significant reductions in soil bulk density and increases in soil nutrient availability persisted for 20 years in hinge position soils relative to undisturbed (control) soil between trenches. These effects on bulk density and nutrient availability are associated with significant differences in pine size by year 6. Burning and planting positions interacted significantly in their effect on pine height, diameter, and stem volume for at least 19 years. Pine survival was high regardless of burning or planting position. Neither broadcast burning nor planting position significantly affected lodgepole pine foliar nutrient status in this study.

\section{Introduction}

The preparation of harvested forest sites to improve conditions for the establishment of conifer seedlings is a common northern hemisphere practice, especially in North America and Scandinavia [1]. In boreal and subboreal regions of British Columbia, Canada, low soil and air temperature, excess soil moisture, and poor soil aeration [1] are the most common limitations to seedling establishment. Mechanical site preparation (MSP) and prescribed fire [2] are the most common approaches to ameliorating these problems. They are also applied to reduce slash loads and improve access for tree planting on some sites. Mechanical site preparation has been more extensively used than prescribed fire for about three decades in British Columbia, largely because of concerns about air quality $[3,4]$. In recent years, mechanical preparation of sites has also declined due to concerns about soil degradation [5-7] and cost. Mechanical site preparation may be a cost-effective measure for enhancing softwood timber production and shortening rotation length on some sites [8], but protection of the soil resource [9] and the effects of these treatments on soil carbon content [1012] must also be primary considerations. Site preparation treatments that enhance conifer establishment and early growth have the potential to enhance carbon sequestration in the standing forest, but they can also be responsible for losses of soil carbon through acceleration of biological processes and long-term decreases in nutrient capital [13-17] and ectomycorrhizal presence [18].

Mechanical treatments that remove or invert forest floor materials or mix mineral and organic layers affect soil bulk density, moisture, and thermal characteristics [19]. In turn, 
these effects may increase short-term nutrient availability by accelerating soil chemical and biological processes [20-22]. Prescribed fire, on the other hand, does not physically disrupt the soil matrix but depending on the fire intensity [23], it may affect soil moisture and thermal characteristics through the reduction of surface organic material, oxidation of soil organic material, and creation of a hydrophobic surface layer $[4,17]$. Increases in $\mathrm{pH}$ that occur following oxidation of organic compounds and the deposition of ash on the soil surface often increase short-term nutrient availability [24]; however, substantial nutrient loss also occurs through the volatilization of slash and forest floor materials, leaching of soluble ash components, and movement of fine particulate matter by wind $[17,22,25]$. From the perspective of conifer nutrition, treatment effects on nitrogen, sulphur, and boron availability are of special interest because these nutrients are frequently limiting to tree growth on forested sites in northcentral British Columbia [26-29].

A wide range of boreal and subboreal studies was established in the mid-1980s to investigate conifer seedling survival and growth responses to MSP (e.g., [30-33]). In some cases, soil and foliar data were also collected to examine long-term effects on soil properties and tree nutrition [34, 35]. In that era, prescribed fire was still a common site preparation technique on high elevation sites in British Columbia. It was sometimes used in combination with disk trenching, but no information was available to determine whether this practice was detrimental to site quality or even beneficial to conifer performance. In 1988, a study was established to examine the individual and combined effects of broadcast-burning and disk-trenching planting position on physical and chemical characteristics of the soil, as well as on survival, growth, and foliar nutrition of lodgepole pine (Pinus contorta Dougl.ex Loud. var. latifolia Englm.). Specific objectives were (a) to compare the long-term effects of disk trenching alone and disk trenching following a low-impact broadcast burn on soil characteristics and lodgepole pine growth and foliar nutrition, (b) to compare the effects of hinge and trench planting positions (created by disk trenching) with an untreated planting position on soil characteristics and lodgepole pine growth and foliar nutrition, (c) to examine interactions between burning and planting position to determine whether conifer performance could be enhanced beyond improvements resulting from selection of planting position alone, and (d) to quantify treatment effects on surface soil carbon content at the site.

\section{Materials and Methods}

2.1. Study Site. The Tanli site $\left(53^{\circ} 17^{\prime} \mathrm{N} / 124^{\circ} 28^{\prime} \mathrm{W}\right)$ is at an elevation of $1240 \mathrm{~m}$ in the Kluskus Moist Cold SBS biogeoclimatic variant (SBSmc3) [36]. Based on climate means generated for 1971-2000 using ClimateBC [37], the site is characterized by a mean annual temperature of $1.2^{\circ} \mathrm{C}$, mean annual precipitation of $562 \mathrm{~mm}$, mean annual snowfall of $221 \mathrm{~cm}$, and an average frost-free period of 36 days. The site has a south-easterly aspect and shallow (2\%) slope. Soils range from Orthic Dystric Brunisols to Brunisolic Gray Luvisols [38], fine to coarse loamy in texture, with 15-25\% coarse fragments, an effective rooting depth of 5-25 cm, and a Hemimor humus form ranging in depth from 4 to $6 \mathrm{~cm}$. Parent material is a fine, loamy morainal blanket with inclusions of a fine loamy lacustrine veneer. The site is mesic to subhygric. The predominant site series are 01 and 04 , which are characterized by $30-50 \%$ cover of low shrub species such as prickly rose (Rosa acicularis), black twinberry (Lonicera involucrata), black huckleberry (Vaccinium membranaceum), highbush cranberry (Viburnum edule), birch-leaved spirea (Spiraea betulifolia), and soopolallie (Shepherdia canadensis) and a low herb community that typically has $40-55 \%$ cover [36]. There were also minor areas of site series 07 which are typified by greater black twinberry cover. The site was clearcut harvested and grapple-skidded in 1985/86.

2.2. Experimental Design and Treatments. The experiment employed a split-plot design with two treatments (disk trenching alone or controlled broadcast burning plus disk trenching), each randomly assigned to a large (approximately 3 hectare) single main plot. The low-impact [23] controlled burn was applied to one main plot (one half of the study area) in fall 1986. In autumn 1987, a Wadell powered scarifier was used to create trenches in both burned and unburned main plots. Trenches were spaced approximately $3.3 \mathrm{~m}$ apart (centre to centre) and were about $60 \mathrm{~cm}$ wide and $11 \mathrm{~cm}$ deep. The adjacent continuous berms were approximately $20 \mathrm{~cm}$ deep and $55 \mathrm{~cm}$ wide and were composed of a single sloping layer of forest floor material leading into a mineral soil capping. Four subplots, each measuring approximately $30 \mathrm{~m} \times 60 \mathrm{~m}$ and containing nine 60-metre long disk trenches, were established in each of the unburned or burned main plots. Within subplots, three disk trenches were randomly assigned to each of three planting positions: control (untreated area between trenches), hinge (lower slope of the berm), or trench (bottom of furrow). The assigned planting positions were located along or between (in the case of the control) the respective trenches, with only one of the three possible positions occupying any given trench. The result was six burning-planting position combinations: unburned control (UB-C), unburned hinge (UB-H), unburned trench (UB-T), burn control (B-C), burn hinge (B-H), and burn trench (B-T). In spring 1988, 75 lodgepole pine container seedlings (PSB $2111+0$ ) were planted in each of the control, hinge, or trench positions, for a total of 225 seedlings per subplot. Seedlings were planted approximately $2.2 \mathrm{~m}$ apart in their assigned planting position along or between (in the case of control seedlings) the trenches. Twenty-five seedlings were initially planted in each row. However, subsequent rejection of seedlings in excessively wet areas of the site reduced the total sample size to 1503 measurable seedlings, comprising 200-300 seedlings in each of the six burningposition combinations. Control seedlings were planted with the root collar $1-2 \mathrm{~cm}$ below the mineral soil surface, hinge seedlings were planted through overturned forest floor material into mineral soil between the trench and the berm, and trench seedlings were planted to the root collar in trench bottoms. Due to the technical difficulties of controlling a broadcast burn within small, discrete blocks on a single site and the high cost of installing this type of experiment on 
multiple sites, the main-plot treatments were not replicated on other blocks or sites (i.e., there is only one block with two main plots: (1) unburned and disk trenched and (2) burned and disk trenched).

Limited growing season microclimate data (May 1 to September 30) were collected to characterize growing conditions in the treatment plots and to assist with the interpretation of results. Data were collected from year 7 (1994) to year 9 (1996) in the burned plot and only in year 7 in the unburned plot. One climate monitoring station was installed in each of the unburned and burned plots, each consisting of a Campbell Scientific CR-10 datalogger connected to Campbell Scientific 107 configured soil temperature thermistors and Campbell Scientific 221 or 223 gypsum soil moisture blocks. For the hinge position, thermistors and moisture blocks were installed at a depth of $5 \mathrm{~cm}$ to avoid loose material; two thermistors and one moisture block were installed in the unburned plot and one thermistor and one moisture block were installed in the burned plot. To characterize the control position, thermistors and moisture blocks were installed at a mineral soil depth of $2 \mathrm{~cm}$ (two thermistors and one moisture block in the unburned plot and one thermistor and one moisture block in the burned plot). Conditions in the trench bottom were characterized only for the burned plot; one thermistor and one moisture block were installed at a mineral soil depth of $2 \mathrm{~cm}$.

\subsection{Soil and Foliar Sampling and Laboratory Analysis}

2.3.1. Soil Bulk Density. Posttreatment soil sampling for mineral soil bulk density determination was done 10 and 20 years after disk trenching. Both assessments were carried out between mid-June and mid-July. Samples were taken at a depth of $0-10 \mathrm{~cm}$, with samples collected from all burning-position combinations in year 10, but only from the UB-C, UB-H, and B-C burning-position combinations in year 20. At each sampling date and for each sampled burning-position combination, three lodgepole pine trees were randomly selected as sampling centres. At each selected pine tree, three soil sample locations were selected to be as evenly distributed around the tree as possible while still being representative of the intended planting position. Samples were collected using $3 \times 10 \mathrm{~cm}$ or $10 \times 10 \mathrm{~cm}$ stainless steel cylinders according to the desired sampling depth. In the laboratory, the mineral soil samples were air-dried, weighed, and sieved through a $2 \mathrm{~mm}$ mesh, with rolling or crushing to break up the aggregates. The $<2 \mathrm{~mm}$ (fine) and $\geq 2 \mathrm{~mm}$ (coarse) fractions were determined. A portion of each fine fraction was oven-dried to a constant weight at $105^{\circ} \mathrm{C}$, and the value was used to derive a moisture correction for the weight of the total fine fraction. Fine fraction bulk density $\left(\mathrm{FFD}_{\mathrm{b}}\right)$ was obtained by dividing the corrected soil mass by the sample core volume.

2.3.2. Soil Chemistry. Mineral soil samples for chemical analysis were collected in years 10 and 20 at the same time and at the same depth and locations where soil bulk density was sampled. The three samples collected around each lodgepole pine were bulked. Adjacent forest floor material was collected for UB-C and B-C using a $200 \mathrm{~cm}^{2}$ template. In preparation for chemical analysis, mineral soil samples were air-dried, crushed, and sieved to remove material $\geq 2 \mathrm{~mm}$. For the forest floor samples, woody debris, cones, and green tissues were removed, and the remaining material was airdried and milled (Micropul hammer mill) into a powder. Total carbon (C) and nitrogen (N) were determined using a Fisons NA-1500 elemental analyser, and carbon: nitrogen $(\mathrm{C} / \mathrm{N})$ ratios calculated. Carbon content per hectare was calculated for each burning-planting position combination as $\mathrm{C}$ concentration multiplied by the associated measured fine fraction sample bulk density. Carbon content per ha (to a depth of $10 \mathrm{~cm}$ ) was calculated for the site on the basis of the relative widths of the control $(65 \%)$, berm $(17 \%)$, and trench $(18 \%)$ within each $3.3 \mathrm{~m}$ interval between the trenches described in Section 2.2. Available ammonium-N $\left(\mathrm{NH}_{4}-\mathrm{N}\right)$ and nitrate- $\mathrm{N}\left(\mathrm{NO}_{3}-\mathrm{N}\right)$ were extracted with a $2 \mathrm{~N}$ $\mathrm{KCl}$ solution and determined on the Alpkem Flow System IV analyser. Mineralizable N (min-N) was determined using a 2-week anaerobic incubation method [39]. Available P was determined colorimetrically using the Bray P-1 method [40]. Soil pH was measured in a $1: 1$ soil/water ratio, and electrical conductivity (EC) was measured by the saturated paste method [41].

Concentrations of exchangeable calcium $(\mathrm{Ca})$, magnesium $(\mathrm{Mg})$, and potassium $(\mathrm{K})$ and effective cation exchange capacity (CEC) were determined in year 10 by the $1 \mathrm{~N}$ ammonium acetate $\left(\mathrm{CH}_{3} \mathrm{CO}_{2} \mathrm{NH}_{4}\right)$ at $\mathrm{pH} 7.0$ extraction method, followed by the measurement of cation concentrations by atomic absorption spectrophotometry [42]. In year 20, exchangeable $\mathrm{Ca}, \mathrm{Mg}, \mathrm{K}$, and effective CEC were extracted using the $0.1 \mathrm{~N}$ barium chloride method [43]. Percent base saturation was calculated as $[(\mathrm{Ca}+\mathrm{Mg}+\mathrm{K}) / \mathrm{CEC} * 100)]$.

2.3.3. Lodgepole Pine Foliar Analysis. In September of years 10 and 20, foliage was collected from the same randomly selected lodgepole pine trees where soil samples were taken. Foliar samples were taken from three evenly distributed points around the crown as described by Brockley [27] and bulked for each tree. Following oven drying at $70^{\circ} \mathrm{C}, 100$ needle weights were determined in triplicate and samples were milled into powder in a Tectatot Cyclotec Mill. In year 10, samples were digested using a sulphuric acid-peroxide $\left(\mathrm{H}_{2} \mathrm{SO}_{4}-\mathrm{H}_{2} \mathrm{O}_{2}\right)$ procedure [44] and analysed colorimetrically for $\mathrm{N}$ and $\mathrm{P}$ using a Technicon autoanalyser. Calcium, $\mathrm{Mg}$, and $\mathrm{K}$ were analysed on $\mathrm{H}_{2} \mathrm{SO}_{4}-\mathrm{H}_{2} \mathrm{O}_{2}$ digests using a PerkinElmer atomic absorption spectrophotometer. Total $\mathrm{S}$ was determined using a Leco SC-132 S analyser. Boron (B) was determined by dry ashing followed by the azomethine $\mathrm{H}$ colorimetric method [45]. Copper $(\mathrm{Cu})$, Iron $(\mathrm{Fe})$, manganese $(\mathrm{Mn})$, aluminium $(\mathrm{Al})$, and zinc $(\mathrm{Zn})$ were determined by atomic absorption spectrophotometry following dry ashing. In year 20, a Fisons NA-1500 Combustion Elemental Analyser was used to determine C, N, and S. Active Fe was determined using a Leeman Prodigy ICP, following a 24-hour digestion in $1 \mathrm{~N} \mathrm{HCl}$. Sulphate-S $\left(\mathrm{SO}_{4}-\mathrm{S}\right)$ was analysed using Waters Ltd. Ion Chromatographic Analysis, following a hot $0.01 \mathrm{~N} \mathrm{HCl}$ extraction. Macronutrients and micronutrients $(\mathrm{Ca}, \mathrm{K}, \mathrm{Mg}, \mathrm{P}, \mathrm{Cu}, \mathrm{Fe}, \mathrm{Mn}, \mathrm{Zn}$, and $\mathrm{B})$ were digested 
by the closed-vessel microwave acid digestion method and analysed using a Leeman Prodigy ICP.

2.4. Conifer Measurements. Lodgepole pine survival was assessed after the first growing season in 1988, annually from year 2 to year 16, and in year 19 (2006). Height and groundlevel diameter (GLD) were measured in years 6 (1993), 10 (1997), and 19 (2006). Height: diameter ratio (HDR) and volume index per stem $(V)$ were calculated using height $(H)$ and GLD, both measured in $\mathrm{cm}$, where $V\left(\mathrm{~cm}^{3}\right)$ is defined by (1)

$$
V=\pi\left(\frac{\mathrm{GLD}}{2}\right)^{2} \frac{H}{3} .
$$

2.5. Data Analysis. Treatment differences in soil nutrient concentrations (per unit weight), soil carbon content (per unit area), foliar nutrient concentrations and ratios, and lodgepole pine size differences were assessed separately for individual assessment years (where appropriate) by univariate analysis of variance (ANOVA). With the exception of forest floor chemical properties, where only UB-C and B-C were compared, no statistical tests were conducted for year 20 soils or foliar data due to the fact that only three of six burningplanting position combinations were sampled in that year. Sources of variation for ANOVA were the fixed effects of burning/disk-trenching treatment (confounded with main plot effects), planting position and their interactive effect, and the random effects of subplot nested in main plot and tree (soil or nutrient sample) nested in subplot. Standard ANOVA assumptions (normality, homogeneity of variance, etc.) were assessed; data transformations were considered unnecessary (in part due to the relatively large sample sizes) and were not applied. Treatment and planting position effects on year 19 lodgepole pine survival were assessed by logistic regression analysis based on a model with the same effects as the ANOVA model. The statistical significance of differences between all pairs of treatment means (or log odds ratios) was assessed by the Bonferroni method of multiple comparisons $(\alpha=0.05)$. SAS statistical software (PROC MIXED and PROC GLIMMIX) [46] was used for all data analyses. No statistical analysis could be conducted for microclimate variables because data were collected in only one location in each main plot.

\section{Results}

3.1. Soil Bulk Density. In year 10, planting position had a significant effect on mineral soil $\mathrm{FFD}_{\mathrm{b}}$ at a depth of $0-10 \mathrm{~cm}$, with hinge soils having lower bulk density than control or trench soils (Table 1). The main-plot/burning effect (hereafter referred to as the "burning" effect) was not significant and neither was the burning by position $(\mathrm{B} \times \mathrm{P})$ interaction significant. In year 20, the trend of lower $\mathrm{FFD}_{\mathrm{b}}$ in hinge than control soils was still apparent among the burning-planting position combinations that were sampled in both years (Table 1).

\subsection{Soil Chemistry}

3.2.1. Carbon, Nitrogen, and Phosphorus. When forest floor materials in UB-C and $\mathrm{B}-\mathrm{C}$ were compared, there were no significant differences in concentrations of any C- or $\mathrm{N}$-related variables, or available $\mathrm{P}$, in year 10 or year 20 (Table 2). At a mineral soil depth of $0-10 \mathrm{~cm}$, planting position had a significant effect on total $\mathrm{C}$ and $\mathrm{N}, \mathrm{C} / \mathrm{N}, \min -\mathrm{N}$, and available $\mathrm{P}$ in year 10 , but neither burning nor the $\mathrm{B} \times \mathrm{P}$ interaction effects was significant (Table 1). Concentrations of these nutrients and $\mathrm{C} / \mathrm{N}$ were significantly higher in hinge than they were in either control or trench soils in year 10, and this trend continued to year 20 among the burning-position combinations that were sampled (Table 1). Ammonium-N concentration was significantly affected by the $\mathrm{B} \times \mathrm{P}$ interaction, with the result that UB-H soil had significantly higher concentrations than B-H soil, and both had significantly higher concentrations than soils from all other burningposition combinations. By year 20, the concentration of $\mathrm{NH}_{4}-\mathrm{N}$ in UB-H soils had decreased to approximately the same magnitude as that of UB-C and B-C (Table 1). Neither burning nor planting position had a significant effect on year 10 concentrations of $\mathrm{NO}_{3}-\mathrm{N}$, and there were no apparent interactions between these factors. By year 20, concentrations of $\mathrm{NO}_{3}-\mathrm{N}$ in the sampled burning position combinations had declined in comparison with year 10 values (Table 1 ). The decline was most apparent for hinge soils.

On a per hectare basis, soil $\mathrm{C}$ content was approximately the same in UB-C and B-C forest floor materials in year 10 (23-24 Mg ha ${ }^{-1}$ ), whereas by year 20 , the C content in B$\mathrm{C}$ had declined to approximately one-fifth of that of UB-C (Figure 1(a)). In year 10, mineral soil C content to $10 \mathrm{~cm}$ depth was 2-3 times higher in hinge than control or trench soils (Figure 1(b)). By year 20, C content in UB-H had declined to approximately $60 \%$ of the year 10 value, whereas $\mathrm{C}$-content in UB-C and B-C mineral soil was relatively constant from year 10 to year 20 . Based on estimates that areas treated with the Wadell scarifier were $65 \%$ untreated, $17 \%$ trench berm, and $18 \%$ exposed trenches, the total estimated soil C content across the site to a depth of $10 \mathrm{~cm}$ in year 10 was $35 \mathrm{Mg} \mathrm{ha}^{-1}$ in the unburned plot compared with $37 \mathrm{Mgha}^{-1}$ in the burned plot.

3.2.2. $p H, C E C$, and Exchangeable Cations. In year 10, planting position had a significant effect on $\mathrm{pH}$, CEC, concentrations of exchangeable $\mathrm{Ca}, \mathrm{Mg}$, and $\mathrm{K}$, and $\mathrm{EC}$ at a mineral soil depth of $0-10 \mathrm{~cm}$, but neither the burning effect nor the $\mathrm{B} \times \mathrm{P}$ interaction was significant for any $\mathrm{pH}$ related variables (Table 1). Base saturation was not significantly affected by either burning or position in year 10, and neither was the $\mathrm{B} \times \mathrm{P}$ interaction significant. $\mathrm{pH}$ remained relatively stable between years 10 and 20 in the sampled burning-position combinations. CEC and concentrations of exchangeable cations were generally lower in year 20 than year 10, with UB-H soils showing a particularly steep decline in CEC compared with UB-C and B-C.

3.3. Foliar Nutrition. Neither burning nor position had a significant effect on lodgepole pine mean needle weight 


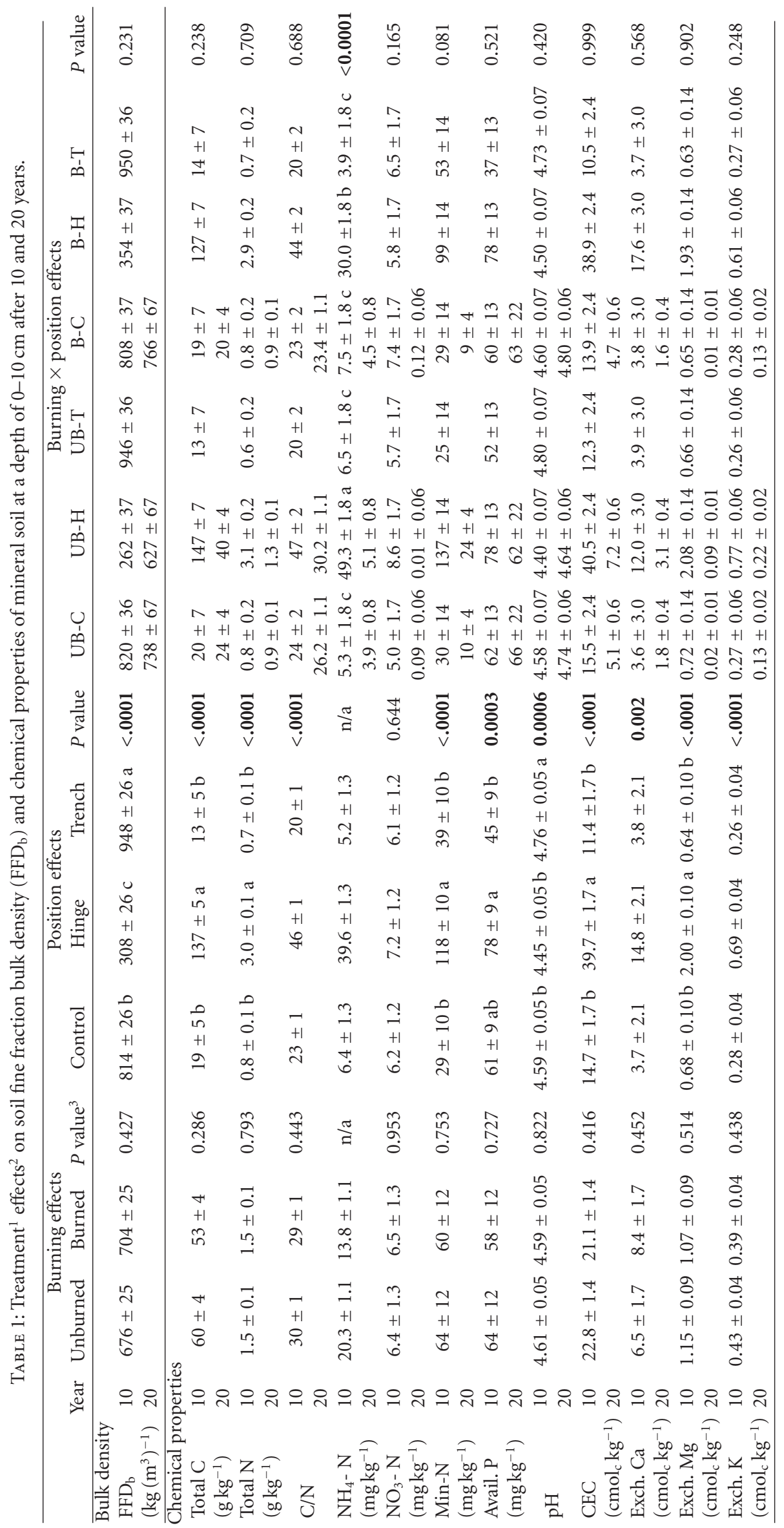




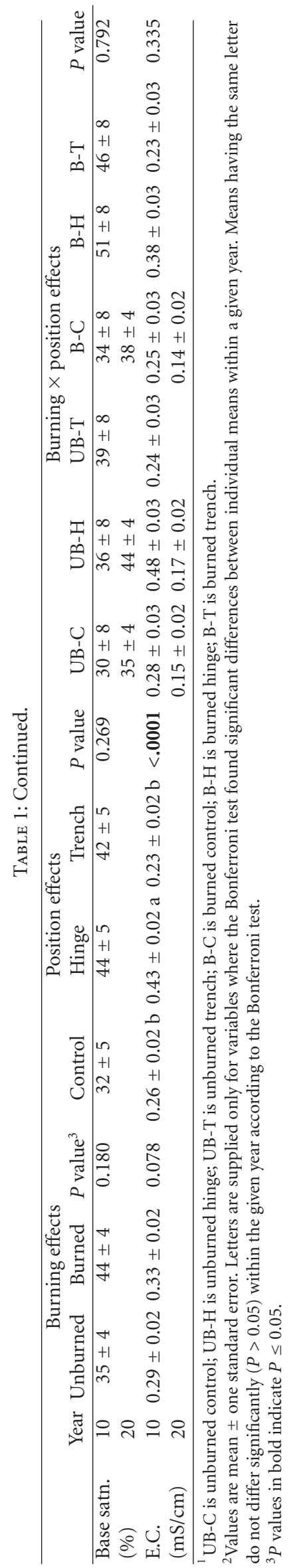




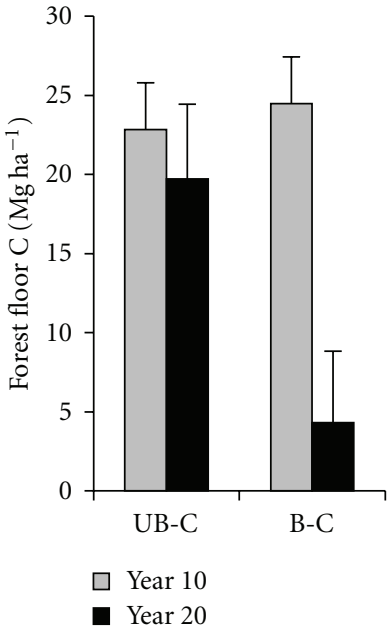

(a)

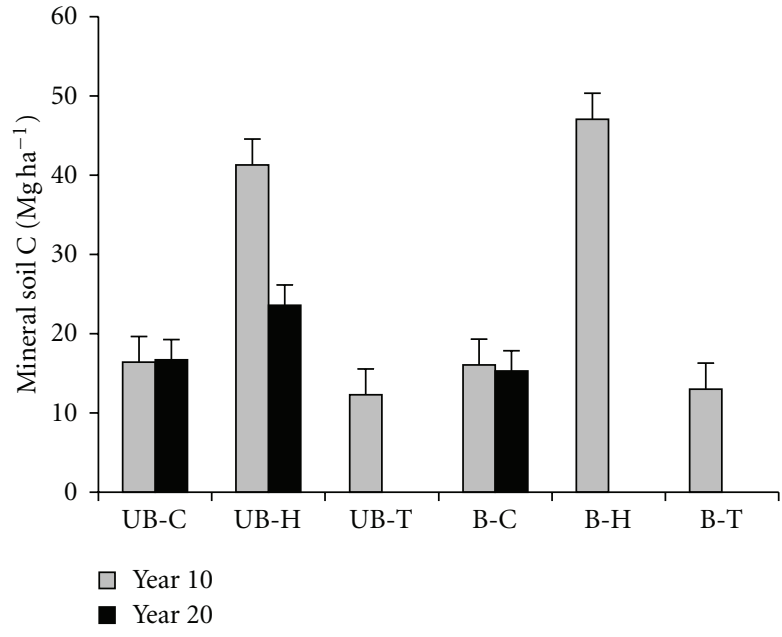

(b)

Figure 1: Soil carbon content $\left(\mathrm{Mg} \mathrm{ha}^{-1}\right)$ in years 10 and 20 in (a) unburned and burned control forest floor and (b) unburned and burned mineral soil to a depth of $10 \mathrm{~cm}$. Error bars are one standard error. Refer to Table 1 for treatment abbreviations.

TABLE 2: Broadcast burning ${ }^{1}$ effects $^{2}$ on forest floor chemistry after 10 and 20 years.

\begin{tabular}{|c|c|c|c|c|c|c|}
\hline & \multicolumn{3}{|c|}{ Year 10} & \multicolumn{3}{|c|}{ Year 20} \\
\hline & UB-C & $\mathrm{B}-\mathrm{C}$ & $P$ value ${ }^{3}$ & UB-C & B-C & $P$ value \\
\hline Total C $\left(\mathrm{g} \mathrm{kg}^{-1}\right)$ & $248 \pm 31$ & $269 \pm 31$ & 0.646 & $329 \pm 20$ & $353 \pm 35$ & 0.576 \\
\hline Total N $\left(\mathrm{g} \mathrm{kg}^{-1}\right)$ & $6.2 \pm 0.9$ & $6.9 \pm 0.9$ & 0.656 & $8.6 \pm 0.5$ & $9.5 \pm 0.9$ & 0.440 \\
\hline $\mathrm{C} / \mathrm{N}$ & $41 \pm 3$ & $39 \pm 3$ & 0.714 & $39 \pm 4$ & $37 \pm 7$ & 0.832 \\
\hline $\mathrm{NH}_{4}-\mathrm{N}\left(\mathrm{mg} \mathrm{kg}^{-1}\right)$ & $149.0 \pm 34.2$ & $103.0 \pm 34.2$ & 0.378 & $33.6 \pm 1.1$ & $29.6 \pm 2.5$ & 0.218 \\
\hline $\mathrm{NO}_{3}-\mathrm{N}\left(\mathrm{mg} \mathrm{kg}^{-1}\right)$ & $49.3 \pm 11.4$ & $22.5 \pm 11.4$ & 0.148 & \multicolumn{2}{|c|}{ missing data } & \\
\hline Min-N & $340 \pm 54$ & $333 \pm 54$ & 0.930 & $217 \pm 51$ & $281 \pm 98$ & 0.592 \\
\hline Avail. P & $116 \pm 34$ & $156 \pm 34$ & 0.432 & $51 \pm 8$ & $73 \pm 14$ & 0.237 \\
\hline $\mathrm{pH}$ & $4.53 \pm 0.12$ & $4.83 \pm 0.12$ & 0.123 & $4.22 \pm 0.13$ & $4.95 \pm 0.30$ & 0.087 \\
\hline $\operatorname{CEC~}\left(\mathrm{cmol}_{\mathrm{c}} \mathrm{kg}^{-1}\right)$ & $69.4 \pm 4.7$ & $76.8 \pm 4.7$ & 0.306 & $33.2 \pm 3.5$ & $47.6 \pm 7.9$ & 0.169 \\
\hline Exch. Ca $\left(\mathrm{cmol}_{\mathrm{c}} \mathrm{kg}^{-1}\right)$ & $17.0 \pm 1.8$ & $25.1 \pm 1.8$ & 0.018 & $21.15 \pm 3.80$ & $37.21 \pm 8.51$ & 0.160 \\
\hline Exch. $\mathrm{Mg}\left(\mathrm{cmol}_{\mathrm{c}} \mathrm{kg}^{-1}\right)$ & $2.63 \pm 0.30$ & $3.71 \pm 0.30$ & 0.041 & $1.74 \pm 1.11$ & $0.59 \pm 1.95$ & 0.636 \\
\hline Exch. K $\left(\mathrm{cmol}_{\mathrm{c}} \mathrm{kg}^{-1}\right)$ & $0.74 \pm 0.08$ & $1.03 \pm 0.08$ & 0.039 & $1.74 \pm 0.38$ & $1.10 \pm 0.67$ & 0.447 \\
\hline Base satn. (\%) & $29 \pm 2$ & $39 \pm 2$ & 0.024 & $73 \pm 10$ & $82 \pm 18$ & 0.681 \\
\hline $\mathrm{EC}(\mathrm{mS} / \mathrm{cm})$ & $0.54 \pm 0.06$ & $0.37 \pm 0.06$ & 0.096 & $0.36 \pm 0.06$ & $0.25 \pm 0.12$ & 0.464 \\
\hline
\end{tabular}

${ }^{1} \mathrm{UB}-\mathrm{C}$ is unburned control; B-C is burned control.

${ }^{2}$ Values are mean \pm one standard error.

${ }^{3} P$ values in bold indicate $P \leq 0.05$.

in year 10 , and the $\mathrm{B} \times \mathrm{P}$ interaction was not significant (Table 3). On average, for burning-position combinations that were sampled in both years, 100 needle weights were 1.6 times higher in year 20 than year 10 (Table 3). None of the tested burning or position effects on foliar concentrations of $\mathrm{N}, \mathrm{P}, \mathrm{K}, \mathrm{Ca}, \mathrm{Mg}$, or $\mathrm{SO}_{4}-\mathrm{S}$ were statistically significant in year 10 (Table 3 ). Foliar $S$ concentrations were significantly higher in burned than unburned plots and also differed significantly as a result of planting position, with higher levels in trench than control or hinge positions (Table 3 ). Foliar nutrient concentrations generally declined between years 10 and 20 in the burning-position combinations that were sampled in both years, with the exception that $\mathrm{Mg}$,
$\mathrm{SO}_{4}-\mathrm{S}$, and $\mathrm{Zn}$ showed slight increases over time. In year 10, planting position had a significant effect on the $\mathrm{N}: \mathrm{Mg}$ foliar nutrient ratio, with values significantly higher in trench than control positions, and on $\mathrm{Ca}: \mathrm{Mg}$ with significantly higher values in trench than hinge positions (Table 4).

3.4. Lodgepole Pine. Lodgepole pine survival was high in all burning-position combinations throughout the study, ranging from $90-94 \%$ in years 6 and 9 after planting, and 90-93\% in year 19. Lodgepole pine height, GLD, and stem volume index were significantly affected by the interaction between burning and planting position in years 6,10 , and 19 (Table 5). In general, lodgepole pine size decreased as a result 


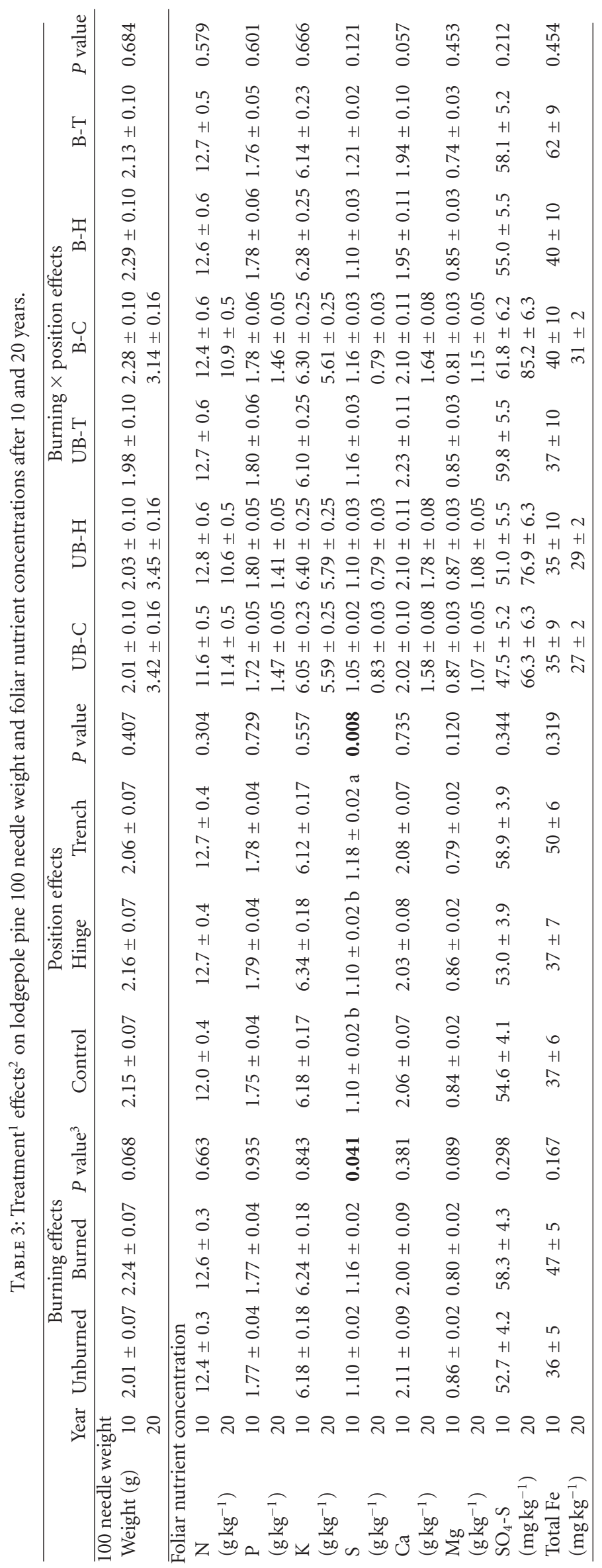




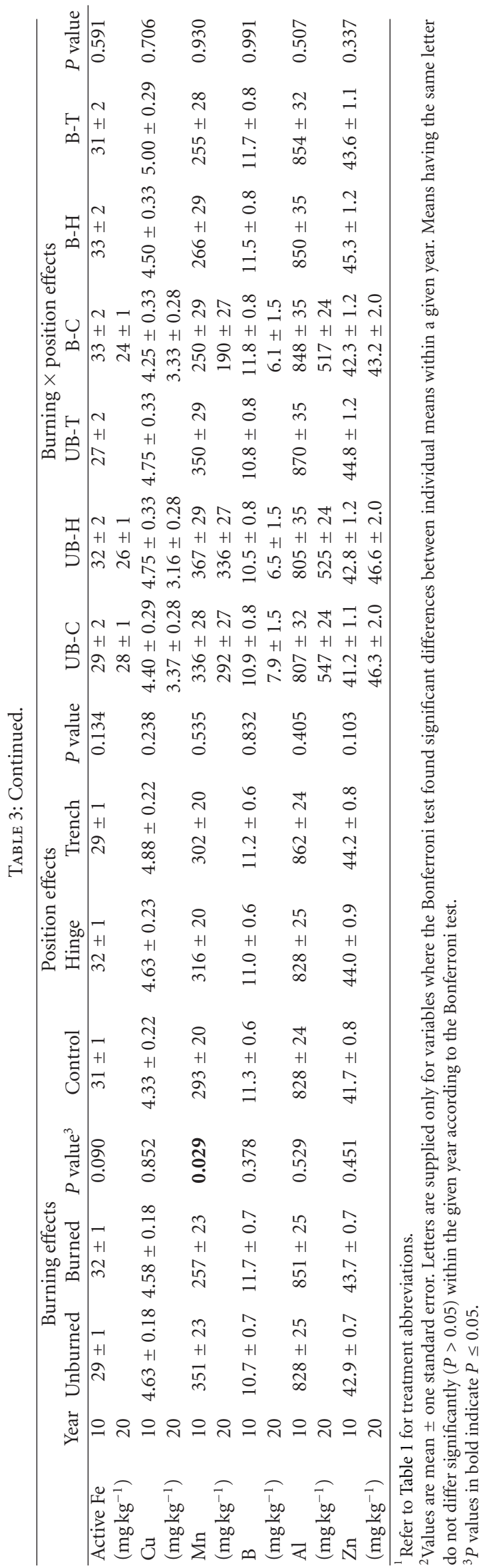




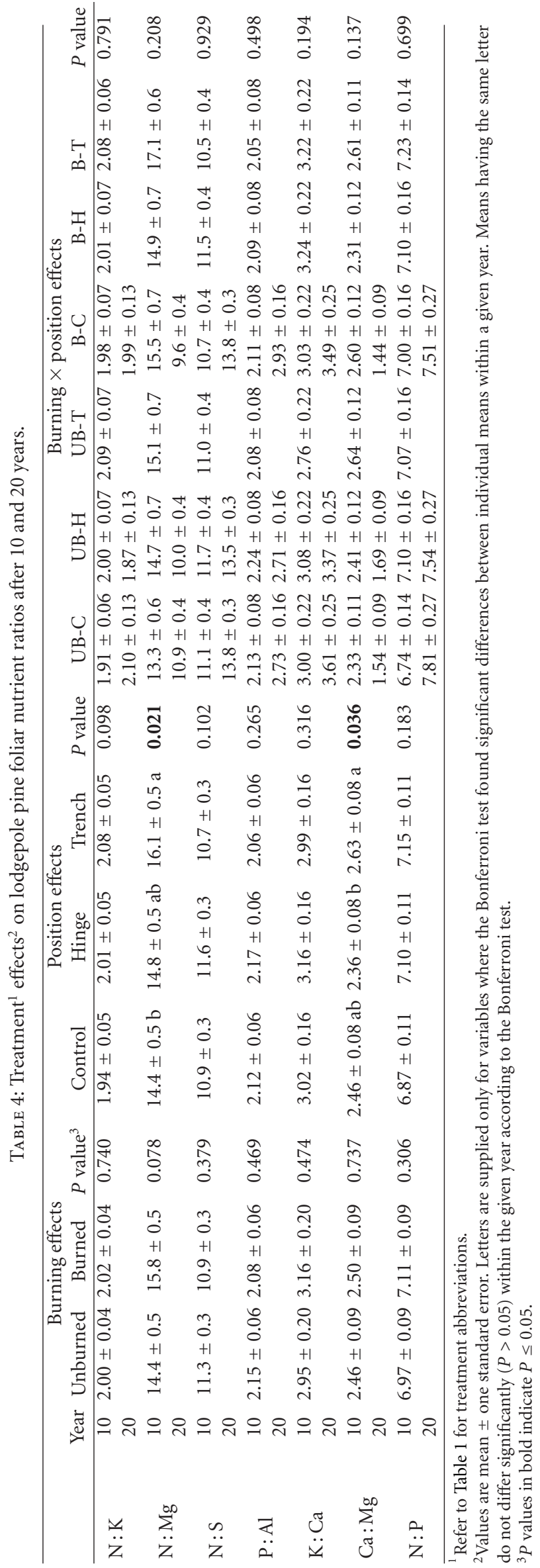




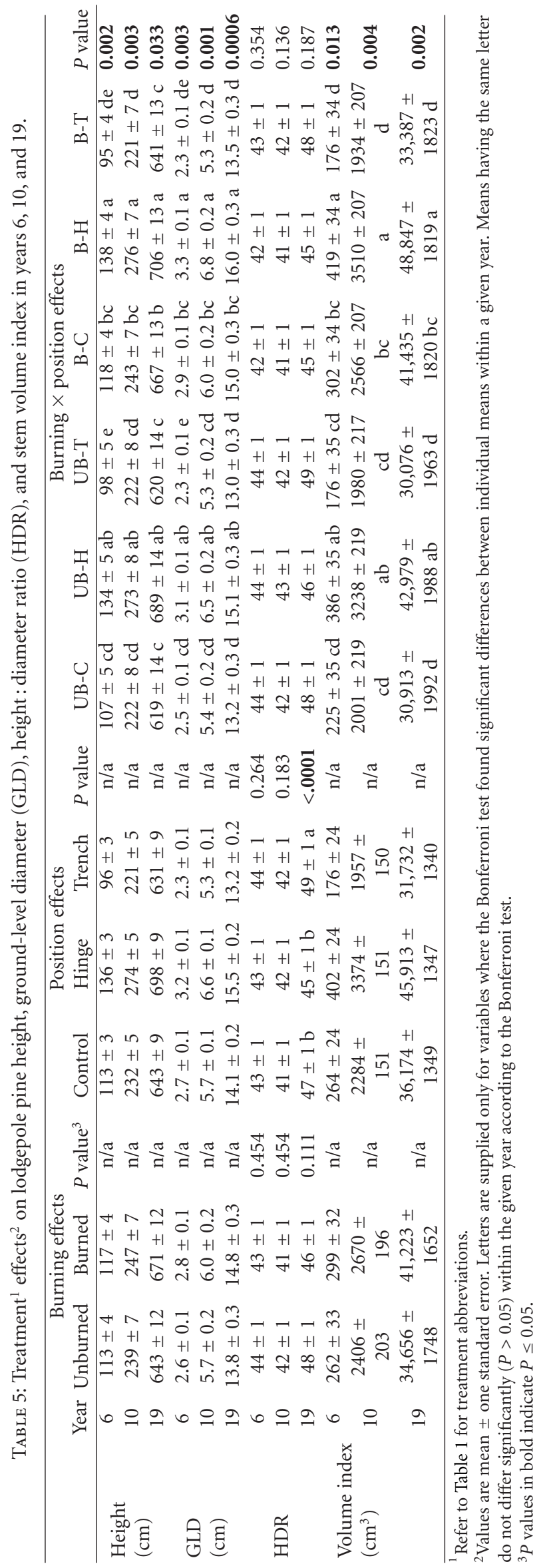


of planting position in the order of hinge $>$ control $>$ trench, with burning providing an apparent additional advantage that resulted in significant separation of the means for individual burning-position combinations. Lodgepole pine height, GLD, and volume did not differ significantly between unburned and burned control, hinge, or trench planting positions in years 6 or 10 (Table 5).

\section{Discussion}

4.1. Soil Bulk Density. Broadcast burning prior to disk trenching did not appear to affect surface soil $(0-10 \mathrm{~cm}$ depth) bulk density in any of the sampled planting positions, which is consistent with the general belief that low intensity prescribed fire has little effect on soil physical structure $[4,23]$ unless the treatment is applied repeatedly [47]. In contrast to the apparent absence of a burning effect, significant differences in $\mathrm{FFD}_{\mathrm{b}}$ between planting positions were created by disk trenching (Table 1). Hinge soils had significantly lower bulk density than control or trench soils in year 10, and the limited sampling that was conducted in year 20 suggests that the trend continued for as long as two decades. Given the negative correlation between organic matter content and bulk density [48, 49], this suggests that forest floor and small slash material deposited in berms by the Wadell scarifier had not completely decomposed over that time period. Management objectives related to reducing mineral soil density are relatively unimportant for sites such as Tanli that have medium soil texture and only moderate sensitivity to compaction [9]. We observed a trend of decreasing $\mathrm{FFD}_{\mathrm{b}}$ over time in the control planting position, which Boateng et al. [50] also reported and attributed to the gradual incorporation of organic matter into mineral soil [48] and to mechanical loosening of the soil by root growth.

4.2. Soil Chemical Properties. The low intensity broadcast burn that was applied prior to disk trenching at the Tanli site appears to have had no effect on organic-matter-related (C, $\mathrm{N}, \mathrm{P}$ ) properties of either the forest floor or surface mineral soil after 10 or 20 years, agreeing with other studies concerning low severity burns $[23,51]$. Broadcast burning may cause minor and short-lived increases in soil $\mathrm{pH}$ [17], but if this occurred at our study site, the effect had disappeared prior to our initial sampling. We did, however, find significantly higher concentrations of exchangeable $\mathrm{Ca}, \mathrm{K}$, and $\mathrm{Mg}$, and higher base saturation that persisted in burned forest floor materials for 10 years. Neff et al. [25] also reported increased Ca concentration in recently burned surface soils, although levels of $\mathrm{K}$ and $\mathrm{Mg}$, which are also noncombustible, were unchanged in that study. Low-impact broadcast burning had no apparent effect on surface mineral soil concentrations of $\mathrm{pH}$-related properties at Tanli, in contrast with the more intense effects of high severity pile and burn treatments that were observed in a related study [50].

In contrast to broadcast burning, planting position at the Tanli site had significant and long-lasting effects on both organic-matter- and $\mathrm{pH}$-related soil properties, presumably due to the concentration of nutrients in the hinge relative to the trench or control positions (Table 1). To the extent that we can report, given the reduced sampling in year 20, these effects persisted for total $\mathrm{C}$ and $\mathrm{N}, \mathrm{C} / \mathrm{N}, \mathrm{CEC}$, and exchangeable $\mathrm{Ca}, \mathrm{Mg}$, and $\mathrm{K}$. The longevity of elevated nutrient levels is attributed to ongoing decomposition, nitrification, and nutrient release associated with organic matter incorporated into the raised berms created by the Waddell scarifier [1, 52]. Many studies have documented increases in soil nutrient availability in raised, mechanically prepared beds. In some, the effects have been limited to organic matter-related properties [15], whereas others have reported increased availability of $\mathrm{P}, \mathrm{N}$, and also increased CEC or exchangeable cation levels $[20,21,34]$. With the exception of $\mathrm{NH}_{4}-\mathrm{N}$, there were virtually no detectable interactions between burning and planting position for soil chemistry variables studied at Tanli (Table 1).

Enhancing the availability of nutrients for early conifer tree growth is obviously important from a forest management perspective. In British Columbia, this is particularly true of $\mathrm{N}$ and $\mathrm{S}$ which are commonly deficient $[26,53]$. Mineralizable- $\mathrm{N}$ is an accepted index of nitrogen availability for plant uptake [26], although it has lately been recognized that organic $\mathrm{N}$ may also contribute to plant nutrition, especially in ecosystems where $\mathrm{N}$ supplies are limited [54]. Hinge position soils at Tanli had significantly higher levels of min- $\mathrm{N}$ and $\mathrm{NH}_{4}-\mathrm{N}$ at a depth of $0-10 \mathrm{~cm}$ in year 10 , and for min-N, this trend continued to year 20 (24 versus $10 \mathrm{mg} \mathrm{kg}^{-1}$ for min-N). Nitrate-N is highly leachable [55, $56]$, which may partly explain why, by year 10 , increases could not be detected in the surface $0-10 \mathrm{~cm}$ of mineral soil for any burning-position combination, and also why there was a profound decline in this form of nitrogen between years 10 and 20 (Table 1). Mineralization rates, uptake by plants, and seasonal variation in N cycling [24] may also have contributed to the differences since $\mathrm{N}$ availability is strongly linked to biological processes.

The effects of silvicultural treatments on carbon sequestration are becoming increasingly important, particularly in northern ecosystems where the effects of climate change are predicted to be strongest [57]. Boreal forest floor materials contain a large proportion of available nutrient capital, and treatments that disturb them can have both short- and longterm, positive or negative, effects [22]. Site preparation can accelerate the loss of forest floor carbon but may also remove constraints to tree growth and offset long-term declines in forest productivity [58]. Approximately two-thirds of site carbon in mature sub-boreal stands is held in standing timber [12], which suggests that treatments such as disk trenching that facilitate rapid regeneration and tree growth while disrupting less than $50 \%$ of the ground surface area [59] are a desirable option. We found that disk trenching rearranged the distribution of soil carbon in the different planting positions, but after 10 years had had very little effect on soil $\mathrm{C}$ content (to a depth of $10 \mathrm{~cm}$ ) for the site. There were greater declines in forest floor carbon content in burned than unburned plots between years 10 and 20 (Figure 1(a)). This may be related to a structural change to forest floor materials that resulted from burning [25] or to the consumption of small woody debris that eventually decomposed in the unburned plot. 


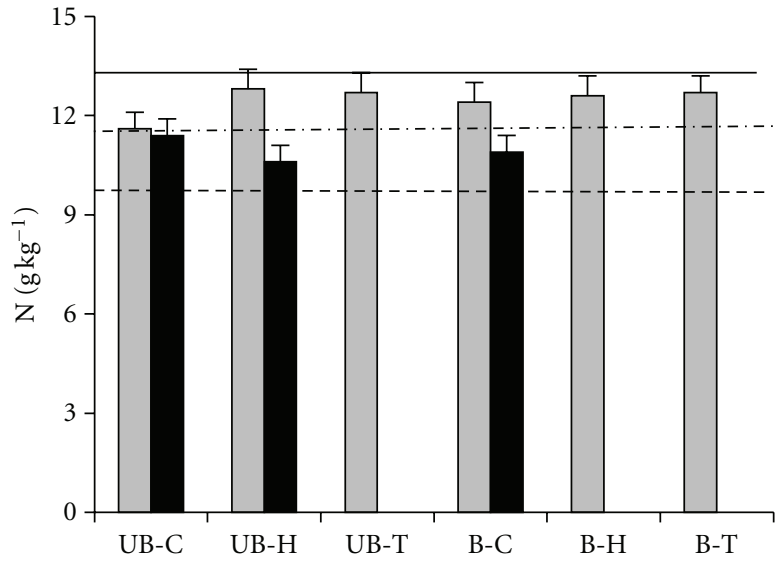

(a)

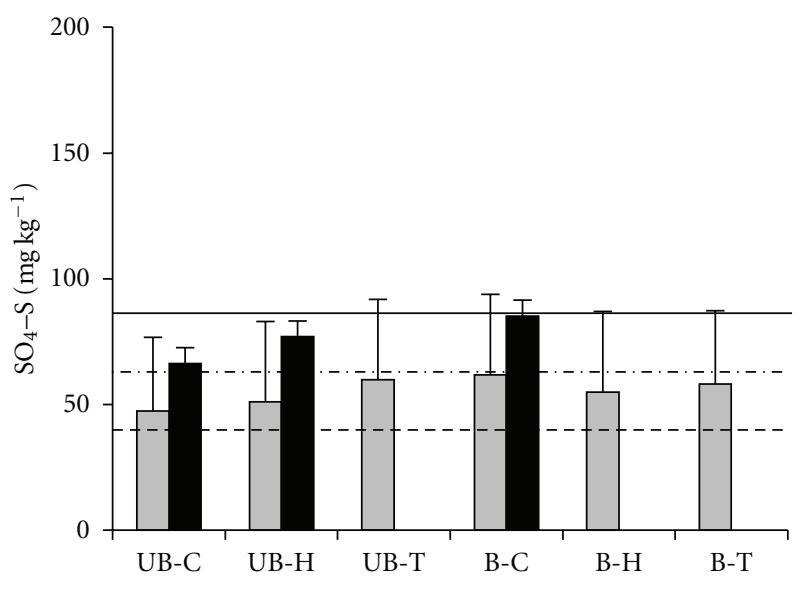

(c)

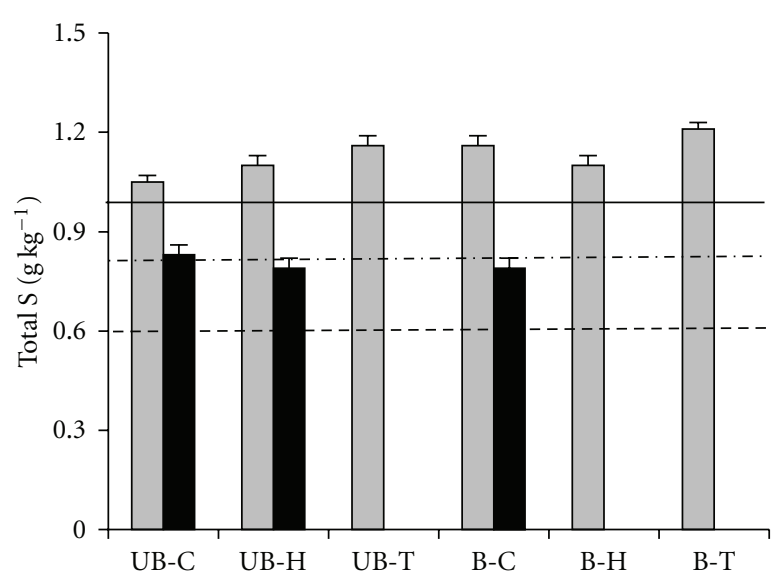

(b)

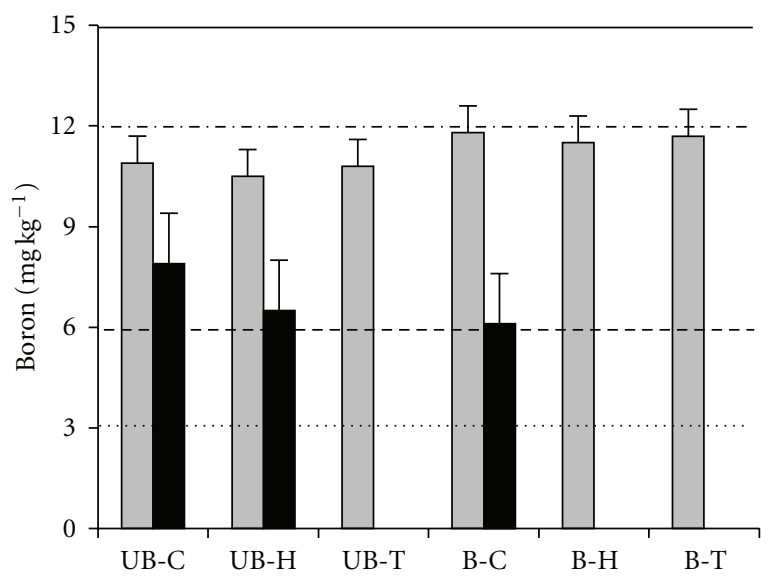

(d)

Figure 2: Mean foliar concentrations of (a) total $\mathrm{N}\left(\mathrm{g} \mathrm{kg}^{-1}\right)$, (b) total S $\left(\mathrm{g} \mathrm{kg}^{-1}\right)$, (c) $\mathrm{SO}_{4}-\mathrm{S}\left(\mathrm{mg} \mathrm{kg}^{-1}\right)$, and (d) B (mg kg-1) in years 10 (gray bars) and 20 (black bars). Error bars are one standard error. Refer to Table 3 for Bonferroni mean separation. For $\mathrm{N}, \mathrm{S}$, and $\mathrm{SO}_{4}-\mathrm{S}$, concentrations are adequate above the solid line, slightly to moderately deficient between the solid and dashed-dotted lines, moderately to severely deficient between the dashed-dotted and dashed lines, and severely deficient below the dashed lines. For boron, concentrations are adequate above the solid line, likely not deficient between the solid and dashed-dotted line, possibly deficient between the dashed-dotted and dashed lines, probably deficient between the dashed and dotted lines, and severely deficient below the dotted line (based on Brockley [27]). Refer to Table 1 footnotes for treatment abbreviations.

4.3. Foliar Nutrient Responses. Broadcast burning and planting position had very few significant effects on foliar nutrient concentration or nutrient ratios and showed no significant interaction with each other. Concentrations of most nutrients declined between years 10 and 20 across all burning-position combinations, which probably reflects the developing stand drawing more heavily on site nutrient supplies. According to criteria suggested by Brockley [27], foliar $\mathrm{N}$ was slightly to moderately deficient in year 10 . This deficiency continued to year 20, worsening for lodgepole pine growing in UB-H and B-C (Figure 2(a)). Nitrogen deficiency is common on central and northern interior sites in British Columbia due to the effects of low soil temperature on mineralization rates [26]. Deficiencies of sulphur, an element important to tree nutrition because of its role in amino acid and protein synthesis [60], are also widespread on interior British Columbia sites [53]. Foliar S concentrations
(Figure $2(\mathrm{~b})$ ) and the N:S ratio suggested no deficiency in year 10 at Tanli. In contrast, year 10 concentrations of $\mathrm{SO}_{4}-\mathrm{S}$, a form of sulphur that is usable by trees [26], indicate moderate-to-severe year 10 deficiency in all six burning-position combinations and slight-to-moderate year 20 deficiency in burning-position combinations sampled in that year (Figure 2(c)). Foliar $\mathrm{S}$ was the only macronutrient that appeared to be significantly affected by burning, with slightly higher year 10 concentrations for lodgepole pine in the burned than unburned plot.

Boron is also important to lodgepole pine nutrition in British Columbia. Deficiencies are common in northcentral regions of the province, particularly on sites with glacial moraine soils derived from igneous rocks, with thin surface organic layers [28]. At the levels we report in our study, visible symptoms of B deficiency were unlikely to be present on lodgepole pine, but height development could be 
TABLE 6: Average growing degree days, soil moisture tension, and number of days with soil water tension $>5$ bars in individual treatments ${ }^{1}$ for the period of June 1 to September in years 7-9 after planting (1994 to 1996).

\begin{tabular}{|c|c|c|c|c|c|c|}
\hline & \multicolumn{3}{|c|}{ Unburned } & \multicolumn{3}{|c|}{ Burn } \\
\hline & UB-C & UB-H & UB-T & $\mathrm{B}-\mathrm{C}$ & $\mathrm{B}-\mathrm{H}$ & $\mathrm{B}-\mathrm{T}$ \\
\hline \multicolumn{7}{|l|}{$\mathrm{GDD}\left(5^{\circ} \mathrm{C}\right)$} \\
\hline Year 7 (1994) & 810 & 879 & - & 817 & 1007 & 1006 \\
\hline Year 8 (1995) & - & - & - & 809 & 1022 & 980 \\
\hline Year $9(1996)$ & - & - & - & 701 & 844 & 855 \\
\hline \multicolumn{7}{|c|}{ Average soil moisture tension (bars) } \\
\hline Year 7 (1994) & 2.61 & 11.44 & 2.86 & 0.43 & 8.57 & 5.43 \\
\hline Year 8 (1995) & 0.52 & 9.17 & 0.80 & - & - & - \\
\hline Year 9 (1996) & 1.57 & 3.97 & 3.96 & - & - & 一 \\
\hline \multicolumn{7}{|c|}{ Days with $>5$ bars soil tension } \\
\hline Year 7 (1994) & 0 & 70 & - & 17 & 68 & 24 \\
\hline Year 8 (1995) & - & - & - & 0 & 60 & 0 \\
\hline Year 9 (1996) & - & - & - & 12 & 27 & 24 \\
\hline
\end{tabular}

${ }^{1}$ Refer to Table 1 for treatment abbreviations.

suppressed at these subacute levels [28]. In year 10, foliar B concentrations at Tanli suggested a possible deficiency, but were very close to being adequate (Figure $2(\mathrm{~d})$ ). By year 20 , however, they had declined to levels that were probably deficient according to Brockley [27]. Concentrations of other foliar nutrients were adequate according to Brockley [27], and the minor significant effects that were found for $\mathrm{Mn}$, and the $\mathrm{N}: \mathrm{Mg}$ and $\mathrm{Ca}: \mathrm{Mg}$ ratios are considered to have no biological importance.

4.4. Lodgepole Pine. Nineteen-year survival of lodgepole pine was uniformly high in the Tanli study, even where trees had been planted in control positions between disk trenches. While it is possible that the root configuration of control pine may have been somewhat influenced by the presence of adjacent trenches, root excavations of lodgepole pine in a related study [61] suggest that long lateral roots easily change direction to grow along trenches or bypass the trench as litter and organic matter accumulate over time. Therefore, assuming that seedlings in control positions were not substantially influenced by adjacent trenches during the first few years after planting, these results suggest that neither burning nor disk trenching was necessary to establish lodgepole pine on this high elevation SBSmc3 site. Boateng et al. [50] similarly concluded that site preparation was unnecessary to establish container-grown lodgepole pine on a lower elevation SBS site with milder climate. At the Tanli site, survival decreased by an average of $4 \%$ between years 5 and 6 . It is difficult to say what caused the early decline, but the fact that it occurred similarly across all burning-position combinations suggests that climatic or forest health factors, rather than treatment-related factors, were responsible. When the Tanli study was established in the mid-1980s, enhancing seedling survival was a topic of considerable concern, with problems attributed primarily to the harsh environment of subboreal and boreal sites. In fact, as nursery technology and management strategies evolved, the perceived problem of poor survival was resolved by the improved ability for water uptake [62] and overall superior performance of container stock compared with traditional bareroot stock [63].

In contrast to survival, significant treatment effects on lodgepole pine height, diameter, and stem volume index persisted at the Tanli site for at least two decades. Similarly long-lived responses of lodgepole pine to disk trenching have been reported from Scandinavia [32], whereas another subboreal study in British Columbia found that the effects of this treatment declined within a decade [31]. At the Tanli site, differences in lodgepole pine size were apparent by year 6 with significant interactions between burning and position persisting for at least 19 years (Table 5). Broadcast burning apparently enhanced the strong positive effect that planting in the hinge position had on lodgepole pine growth. This may be due to higher soil temperatures in the burned plot, since broadcast burning had virtually no effect on soil bulk density or soil chemistry. Our limited microclimate data indicate that the number of growing degree-days was substantially higher in burned than unburned hinge soils. Soil moisture conditions were somewhat drier in burned than unburned plots (Table 6), which could have contributed to soil warming.

Studies conducted in British Columbia and elsewhere have shown that seedlings planted on raised, mechanically created microsites have enhanced height and stem diameter growth, and greater root proliferation compared with seedlings planted in unprepared ground [30, 32]. These responses are generally attributed to improvements in root zone characteristics that result from the incorporation of organic material into the raised planting bed [21, 30, 64]. In our study, hinge soils had both lower bulk density and higher nutrient availability than control or trench soils, and they were also warmer and better drained (Table 6). Microsite characteristics can be particularly important to early seedling growth, but the effects do not always persist for as long as 20 
years $[33,65]$. Brand [66] concluded that benefits to early seedling performance were maximized where silvicultural treatments improved both the availability of resources and the ability of the trees to utilize them.

\section{Conclusions and Management Implications}

The potential for disk trenching, alone or in combination with broadcast burning, to foster efficient regeneration of lodgepole pine on high elevation sub-boreal sites has traditionally been important from the perspective of timber production, but effective regeneration practices are now equally relevant for meeting carbon sequestration objectives. The broad range of data collected at the Tanli site makes an important interpretive contribution to our understanding of the effects of these site preparation methods on soil properties and juvenile lodgepole pine growth. We acknowledge that the lack of main plot broadcast-burning replication limits our ability to extend conclusions beyond this particular SBSmc3 site; however, the homogeneity of the research area suggests that differences between the main plots can reasonably be attributed to the effects of burning rather than plot variability. We found that lodgepole pine survival at Tanli was comparable for all burning treatment and planting position combinations tested, but that growth for at least two decades appeared to be improved as a result of planting in the hinge position of disk trenching. In the unburned area, although height in the hinge and control positions differed by less than $60 \mathrm{~cm}$ at age 19 , stem volume index was $25 \%$ higher in the hinge than that in the control position. The question of whether the long-term benefits to tree growth and carbon sequestration are cost-effective over a rotation may be addressed by future modelling exercises. Based on our sampling in hinge, trench, and control planting positions over a 20-year period at the Tanli site, disk trenching had no evident negative impacts on site-level soil carbon content. In contrast, the burning treatment, while associated with slightly greater lodgepole pine growth, also resulted in an apparent reduction in site carbon content.

\section{Acknowledgments}

The authors thank Dr. Robert McMinn, Marvin Grismer, BC Ministry of Forests, Lands and Natural Resource Operations (MFLNRO) staff, and contractors who were involved in the initial installation, measurement, and maintenance of the study site. They are also grateful to Anne Macadam and Rick Trowbridge for collection of year 10 soil data and to Marvin Grismer, Cosmin Man, Torsten Kaffanke, and David Sword for soil and foliar sampling in year 20. Their appreciation also goes to Clive Dawson and staff at the MFLNRO Analytical Laboratory (Victoria) for soil and foliar sample preparation and analysis. Thanks are due to John McClarnon, Richard Kabzems, and Allan Powelson of MFLNRO, Phil Comeau of the University of Alberta, and Paul Sanborn of the University of Northern BC (Prince George) for input during preparation of the paper. Funding for the study was provided by MFLNRO, Canada-British Columbia Economic and Regional Development Agreements
(FRDA), Forest Renewal BC (FRBC), and BC Forest Investment Account: Forest Science Program. Funding assistance does not imply endorsement of any statement or information in this paper.

\section{References}

[1] G. Örlander, P. Gemmel, and J. Hunt, "Site preparation: a Swedish overview," FRDA Report 105, Forestry Canada and British Columbia Ministry of Forests, Victoria, Canada, 1990.

[2] British Columbia Ministry of Forests and Range, 2007/08 Annual Service Plan Report, British Columbia Ministry of Forests and Range, Victoria, Canada, 2008.

[3] D. Yole, M. Kranabetter et al., "Effects of site preparation treatments on soil properties - alternatives to broadcast burning in the north-central interior," FRDA Research Memo 230, Forestry Canada and British Columbia Ministry of Forests, Victoria, Canada, 1996.

[4] M. C. Carter and C. D. Foster, "Prescribed burning and productivity in southern pine forests: a review," Forest Ecology and Management, vol. 191, no. 1-3, pp. 93-109, 2004.

[5] A. Costantini, M. R. Nester, and M. Podberscek, "Site preparation for Pinus establishment in south-eastern Queensland 1. Temporal changes in bulk density," Australian Journal of Experimental Agriculture, vol. 35, no. 8, pp. 1151-1158, 1995.

[6] X. Tan, S. X. Chang, and R. Kabzems, "Effects of soil compaction and forest floor removal on soil microbial properties and $\mathrm{N}$ transformations in a boreal forest long-term soil productivity study," Forest Ecology and Management, vol. 217, no. 2-3, pp. 158-170, 2005.

[7] D. S. Page-Dumroese, M. F. Jurgensen, A. E. Tiarks et al., "Soil physical property changes at the North American long-term soil productivity study sites: 1 and 5 years after compaction," Canadian Journal of Forest Research, vol. 36, no. 3, pp. 551564, 2006.

[8] C. B. D. Hawkins, T. W. Steele, and T. Letchford, "The economics of site preparation and the impacts of current forest policy: evidence from central British Columbia," Canadian Journal of Forest Research, vol. 36, no. 2, pp. 482-494, 2006.

[9] M. Curran, B. Fraser, L. Bedford, M. Osberg, and B. Mitchell, "Site preparation strategies to manage soil disturbanceinterior sites," Field Guide Insert 2, British Columbia Ministry of Forests, Victoria, Canada, 1993.

[10] C. L. Goodale, M. J. Apps, R. A. Birdsey et al., "Forest carbon sinks in the Northern Hemisphere," Ecological Applications, vol. 12, no. 3, pp. 891-899, 2002.

[11] J. M. Kranabetter and A. M. Macadam, "Changes in carbon storage of broadcast burn plantations over 20 years," Canadian Journal of Soil Science, vol. 87, no. 1, pp. 93-102, 2007.

[12] J. M. Kranabetter, "Site carbon storage along productivity gradients of a late-seral southern boreal forest," Canadian Journal of Forest Research, vol. 39, no. 5, pp. 1053-1060, 2009.

[13] H. H. Krause and D. Ramlal, "In situ nutrient extraction by resin from forested, clear-cut and site prepared soil," Canadian Journal of Soil Science, vol. 67, no. 4, pp. 943-952, 1987.

[14] A. D. Munson, H. A. Margolis, and D. G. Brand, "Intensive silvicultural treatment: impacts on soil fertility and planted conifer response," Soil Science Society of America Journal, vol. 57, no. 1, pp. 246-255, 1993.

[15] M. G. Schmidt, S. E. Macdonald, and R. L. Rothwell, "Impacts of harvesting and mechanical site preparation on soil chemical properties of mixed-wood boreal forest sites in Alberta," 
Canadian Journal of Soil Science, vol. 76, no. 4, pp. 531-540, 1996.

[16] J. M. Arocena, "Cations in solution from forest soils subjected to forest floor removal and compaction treatments," Forest Ecology and Management, vol. 133, no. 1-2, pp. 71-80, 1999.

[17] T. M. Ballard, "Impacts of forest management on northern forest soils," Forest Ecology and Management, vol. 133, no. 1-2, pp. 37-42, 2000.

[18] L. W. Lazaruk, S. E. Macdonald, and G. Kernaghan, "The effect of mechanical site preparation on ectomycorrhizae of planted white spruce seedlings in conifer-dominated boreal mixedwood forest," Canadian Journal of Forest Research, vol. 38, no. 7, pp. 2072-2079, 2008.

[19] D. Coates and S. Haeussler, "Mechanical site preparation for cold site management," FRDA Memo 160, Forestry Canada and B.C. Ministry of Forests, Victoria, Canada, 1990.

[20] P. M. Attiwill, N. D. Turvey, and M. A. Adams, "Effects of mound-cultivation (bedding) on concentration and conservation of nutrients in a sandy podzol," Forest Ecology and Management, vol. 11, no. 1-2, pp. 97-110, 1985.

[21] D. S. Page-Dumroese, M. F. Jurgensen, R. T. Graham, and A. E. Harvey, "Soil chemical properties of raised planting beds in a northern Idaho forest," Research Paper INT-419, United States Department of Agriculture, Forest Service, 1989.

[22] C. E. Prescott, D. G. Maynard, and R. Laiho, "Humus in northern forests: friend or foe?" Forest Ecology and Management, vol. 133, no. 1-2, pp. 23-36, 2000.

[23] M. P. Curran, B. Chapman, G. D. Hope, and D. Scott, "Largescale erosion and flooding after wildfires: understanding the soil conditions," Tech. Rep. 30, British Columbia Ministry of Forests and Range, Research Branch, Victoria, Canada, 2006.

[24] J. P. Kimmins, Forest Ecology, MacMillan Publishing, New York, NY, USA, 1987.

[25] J. C. Neff, J. W. Harden, and G. Gleixner, "Fire effects on soil organic matter content, composition, and nutrients in boreal interior Alaska," Canadian Journal of Forest Research, vol. 35, no. 9, pp. 2178-2187, 2005.

[26] T. M. Ballard and R. E. Carter, "Evaluating forest stand nutrient status," in Land Management Handbook 20, British Columbia Ministry of Forests, Research Branch, Victoria, Canada, 1986.

[27] R. P. Brockley, "Foliar sampling guidelines and nutrient interpretative criteria for lodgepole pine," Extension Note 52, British Columbia Ministry of Forests, Research Branch, Victoria, Canada, 2001.

[28] R. P. Brockley, "Effects of nitrogen and boron fertilization on foliar boron nutrition and growth in two different lodgepole pine ecosystems," Canadian Journal of Forest Research, vol. 33, no. 6, pp. 988-996, 2003.

[29] P. T. Sanborn, J. Prietzel, and R. P. Brockley, "Soil and lodgepole pine foliar responses to two fertilizer sulphur forms in the sub-boreal spruce zone, central interior British Columbia," Canadian Journal of Forest Research, vol. 35, no. 10, pp. 2316-2322, 2005.

[30] J. L. Heineman, L. Bedford, and D. Sword, "Root system development of 12-year-old white spruce (Picea glauca (Moench) Voss) on a mounded subhygric-mesic site in northern interior British Columbia," Forest Ecology and Management, vol. 123, no. 2-3, pp. 167-177, 1999.

[31] L. Bedford and R. F. Sutton, "Site preparation for establishing lodgepole pine in the sub-boreal spruce zone of interior British Columbia: the Bednesti trial, 10-year results," Forest Ecology and Management, vol. 126, no. 2, pp. 227-238, 2000.
[32] S. Mattsson and U. Bergsten, "Pinus contorta growth in northern Sweden as affected by soil scarification," New Forests, vol. 26, no. 3, pp. 217-231, 2003.

[33] J. O. Boateng, J. L. Heineman, L. Bedford, G. J. Harper, and A. F. L. Nemec, "Long-term effects of site preparation and postplanting vegetation control on Picea glauca survival, growth and predicted yield in boreal British Columbia," Scandinavian Journal of Forest Research, vol. 24, no. 2, pp. 111-129, 2009.

[34] M. D. MacKenzie, M. G. Schmidt, and L. Bedford, "Soil microclimate and nitrogen availability 10 years after mechanical site preparation in northern British Columbia," Canadian Journal of Forest Research, vol. 35, no. 8, pp. 1854-1866, 2005.

[35] A. Macadam and R. Kabzems, "Vegetation management improves early growth of white spruce more than mechanical site preparation treatments," Northern Journal of Applied Forestry, vol. 23, no. 1, pp. 35-46, 2006.

[36] C. Delong, D. Tanner, and M. J. Jull, "A field guide for site identification and interpretation for the southwest portion of the Prince George Forest Region," in Land Management Handbook, no. 24, British Columbia Ministry of Forests, Research Branch, Victoria, Canada, 1993.

[37] T. Wang, A. Hamann, D. L. Spittlehouse, and S. N. Aitken, "Development of scale-free climate data for western Canada for use in resource management," International Journal of Climatology, vol. 26, no. 3, pp. 383-397, 2006.

[38] Soil Classification Working Group, The Canadian System of Soil Classification, Agriculture and Agri-Food Canada, Ottawa, Canada, 1998.

[39] J. M. Bremner, "Nitrogen availability iIndexes," in Methods of Soil Analysis, Part 2, Agronomy 9, C. A. Black, Ed., pp. 1324-1345, American Society of Agronomy, Wis, USA, 1996.

[40] R. H. Bray and L. T. Kurtz, "Determination of total, organic, and available forms of phosphorus in soils," Soil Science, vol. 59, no. 1, pp. 39-45, 1945.

[41] Y. P. Kalra, D. G. Maynard et al., "Methods manual for forest soil and plant analysis," Information Report NOR-X-319, Forestry Canada, 1991.

[42] M. R. Carter, Soil Sampling and Methods of Analysis, Canadian Society of Soil Science, Lewis Publishers, 1991.

[43] W. H. Hendershot and M. Duquette, "A simple barium chloride method for determining cation exchange capacity and exchangeable cations," Soil Science Society of America Journal, vol. 50, no. 3, pp. 605-608, 1986.

[44] J. A. Parkinson and S. E. Allen, "A wet oxidation procedure for the determination of nitrogen and mineral nutrients in biological material," Communications in Soil Science and Plant Analysis, vol. 6, no. 1, pp. 1-11, 1975.

[45] T. P. Gaines and G. A. Mitchell, "Boron determination in plant tissues by the azomethine H method," Communications in Soil Science and Plant Analysis, vol. 10, no. 8, pp. 1099-1108, 1979.

[46] SAS Institute, Inc., SAS 9.2, Cary, NC, USA, 2002-2008.

[47] C. W. Ralston and G. E. Hatchell, "Effects of prescribed burning on physical properties of soil," in Proceedings of the Prescribed Burning Symposium, Charleston, SC, 1971.

[48] M. Prévost, "Predicting soil properties from organic matter content following mechanical site preparation of forest soils," Soil Science Society of America Journal, vol. 68, no. 3, pp. 943-949, 2004.

[49] C. Périé and R. Ouimet, "Organic carbon, organic matter and bulk density relationships in boreal forest soils," Canadian Journal of Soil Science, vol. 88, no. 3, pp. 315-325, 2008.

[50] J. O. Boateng, J. L. Heineman, L. Bedford, and A. F. L. Nemec, "Twenty-year effects of mechanical site preparation and windrow burning treatments on soil properties and 
pinus contorta var. latifolia nutrition in sub-boreal British Columbia," Scandinavian Journal of Forest Research, vol. 25, no. 6, pp. 515-533, 2010.

[51] C. Bulmer, M. G. Schmidt, B. Kishchuk, and C. Preston, "Impacts of blading and burning site preparation on soil properties and site productivity in the sub-boreal spruce zone of central British Columbia," Information Report BC-X-377, Canadian Forest Service, Pacific Forestry Centre, Victoria, B.C., 1998.

[52] A. Lundmark-Thelin and M. B. Johansson, "Influence of mechanical site preparation on decomposition and nutrient dynamics of Norway spruce (Picea abies (L.) Karst.) needle litter and slash needles," Forest Ecology and Management, vol. 96, no. 1-2, pp. 101-110, 1997.

[53] B. E. Kishchuk and R. P. Brockley, "Sulfur availability on lodgepole pine sites in British Columbia," Soil Science Society of America Journal, vol. 66, no. 4, pp. 1325-1333, 2002.

[54] J. P. Schimel and J. Bennett, "Nitrogen mineralization: challenges of a changing paradigm," Ecology, vol. 85, no. 3, pp. 591-602, 2004.

[55] L. N. Overrein, "Lysimeter studies on tracer nitrogen in forest soil: 2. Comparative losses of nitrogen through leaching and volatilization after the addition of urea-, ammonium-, and nitrate- $\mathrm{N}_{15}$," Soil Science, vol. 107, no. 3, pp. 149-159, 1969.

[56] J. Otchere-Boateng and T. M. Ballard, "Urea fertilizer effects on dissolved nutrient concentrations in some forest soils," Soil Science Society of America Journal, vol. 42, no. 3, pp. 503-508, 1978.

[57] D. L. Spittlehouse, "Climate change, impacts, and adaptation scenarios: climate change and forest and range management in British Columbia," Tech. Rep. 045, British Columbia Ministry of Forests, Research Branch, Victoria, Canada, 2008.

[58] S. Haeussler and D. Kneeshaw, "Comparing forest management to natural processes," in Towards Sustainable Management of the Boreal Forest, P. J. Burton, C. Messier, D. W. Smith, and W. L. Adamowicz, Eds., pp. 307-368, National Research Council Research Press, Ottawa, Canada, 2003.

[59] M. A. von der Gönna, "Fundamentals of mechanical site preparation," FRDA Report 178, Forestry Canada and British Columbia Ministry of Forests, Victoria, Canada, 1992.

[60] T. T. Kozlowski and S. G. Pallardy, Physiology of Woody Plants, Academic Press, San Diego, Calif, USA, 2nd edition, 1997.

[61] British Columbia Ministry of Forests, "Bednesti Site: testing the biological effectiveness of mechanical site preparation equipment (15-year results)," 130 pages, MSP tour guide. BC Ministry of Forests Victoria, BC., 2003.

[62] S. C. Grossnickle and T. J. Blake, "Water relation patterns of bare-root and container jack pine and black spruce seedlings planted on boreal cut-over sites," New Forests, vol. 1, no. 2, pp. 101-116, 1987.

[63] N. Thiffault, R. Jobidon, and A. D. Munson, "Performance and physiology of large containerized and bare-root spruce seedlings in relation to scarification and competition in Québec (Canada)," Annals of Forest Science, vol. 60, no. 7, pp. 645-655, 2003.

[64] M. D. Bock and K. C. J. Van Rees, "Mechanical site preparation impacts on soil properties and vegetation communities in the Northwest Territories," Canadian Journal of Forest Research, vol. 32, no. 8, pp. 1381-1392, 2002.

[65] J. O. Boateng, J. L. Heineman, J. McClarnon, and L. Bedford, "Twenty year responses of white spruce to mechanical site preparation and early chemical release in the boreal region of northeastern British Columbia," Canadian Journal of Forest Research, vol. 36, no. 10, pp. 2386-2399, 2006.
[66] D. G. Brand, "The establishment of boreal and sub-boreal conifer plantations: an integrated analysis of environmental conditions and seedling growth," Forest Science, vol. 37, no. 1, pp. 68-100, 1991. 

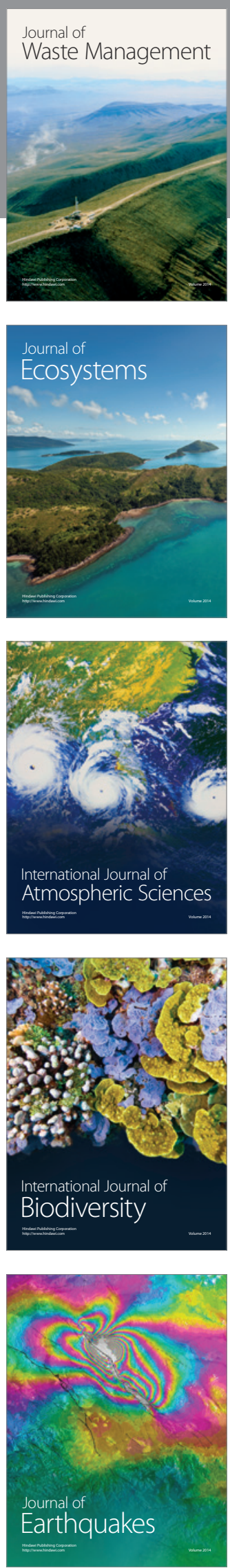
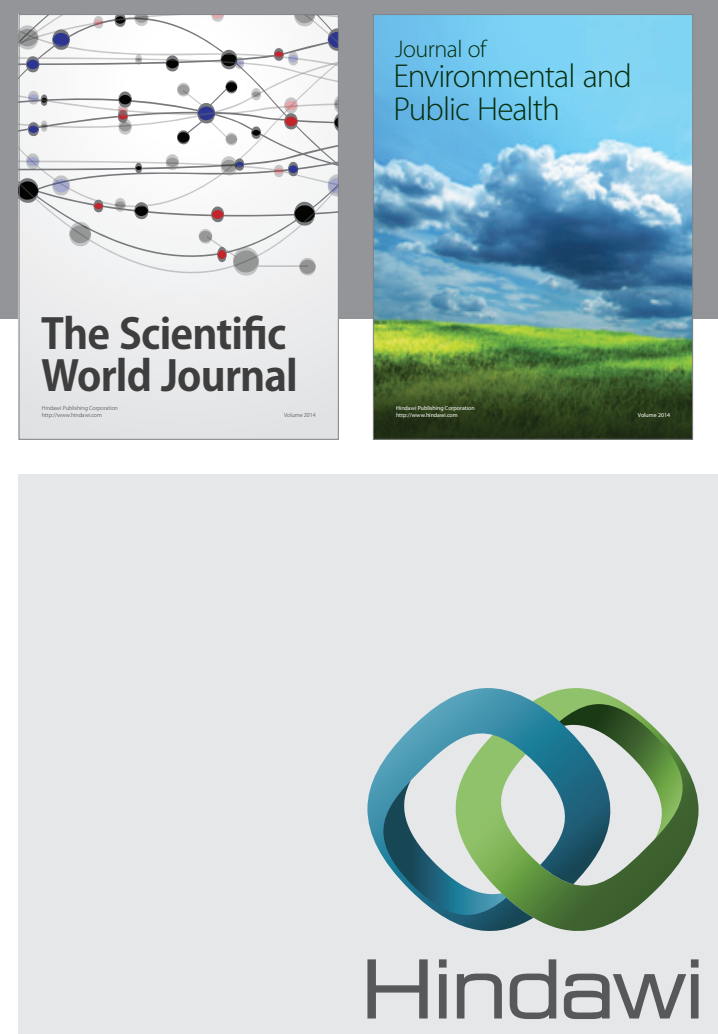

Submit your manuscripts at

http://www.hindawi.com
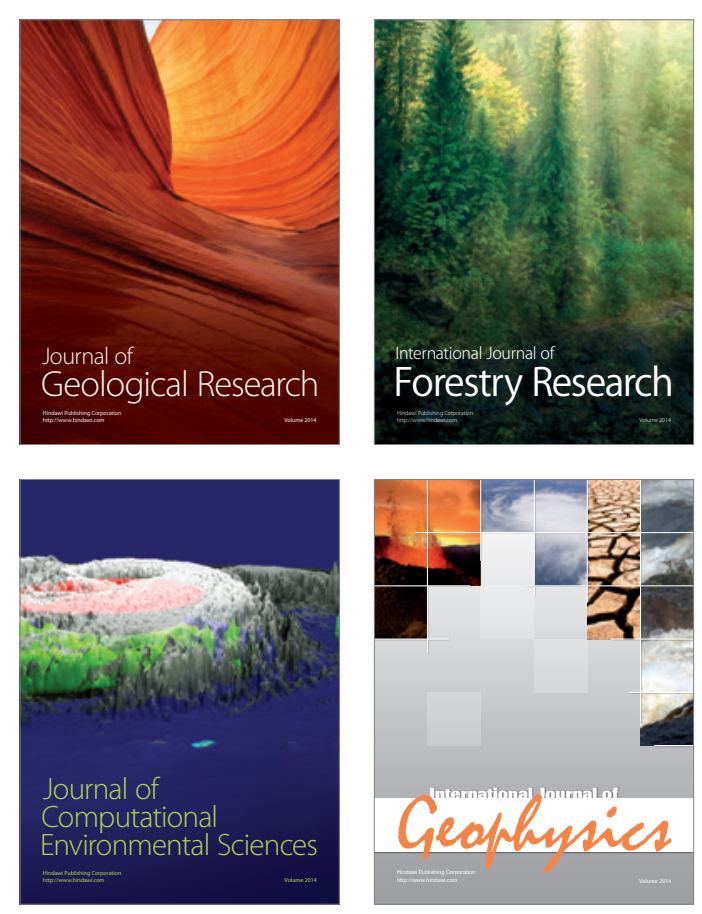
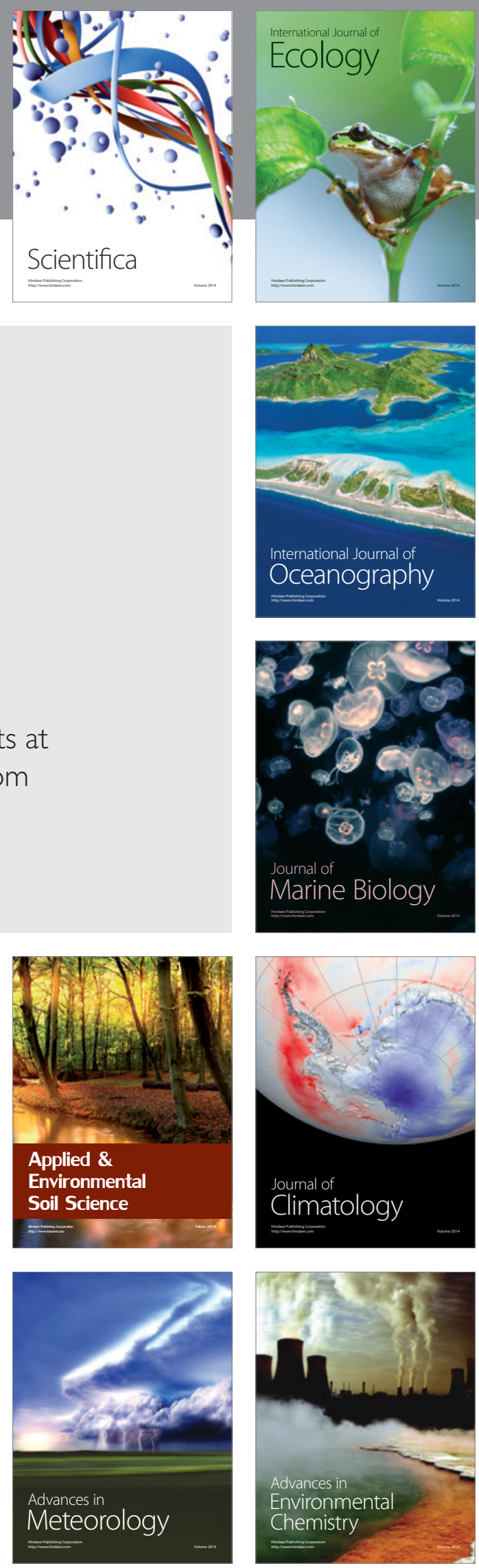